U. S. GEOLOGICAL SURVEY

SAUDI ARABIAN PROJECT REPORT 269

\title{
PALEOCENE VERTEBRATES FROM COASTAL DEPOSITS IN THE HARRAT HADAN AREA, AT TAIF REGION, KINGDOM OF SAUDI ARABIA
}

\author{
by \\ Cary T. Madden, Ibne Mohammed Naqvi, \\ Frank C. Whitmore, Jr., Dwight L. Schmidt, \\ Wann Langston, Jr., and Roger C. Wood
}

U.S. Geological Survey

Jiddah, Saudi Arabia 
The work on which this report is based was performed in accordance with a cooperative agreement between the U. S. Geological Survey and the Ministry of Petroleum and Mineral Resources, Kingdom of Saudi Arabia.

This report is preliminary and has not been edited or reviewed for conformity with U. S. Geological Survey standards and nomenclature. 


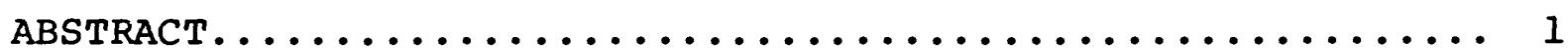

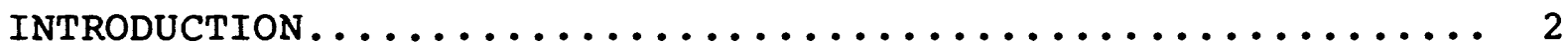

Previous investigations...................... 2

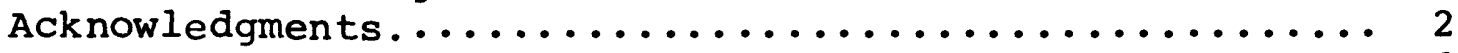

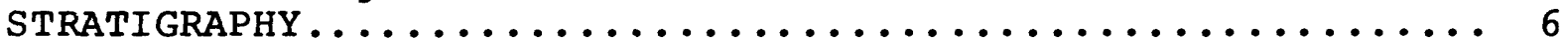

Khurma formation........................ 6

Umm Himar formation........................ 8

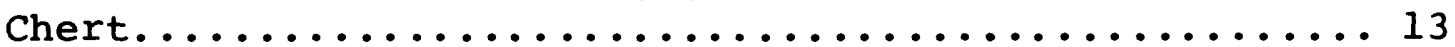

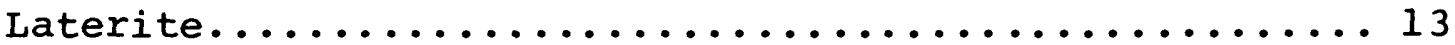

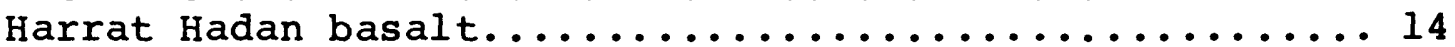

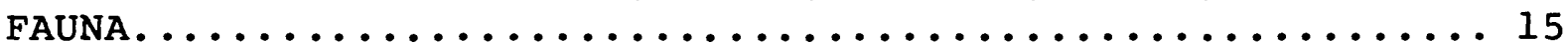

AGE ................................... 18

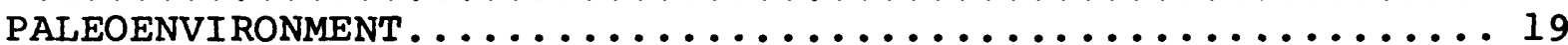

OTHER VERTEBRATE FOSSILS FROM ARABIA................. 22

GEOLOGIC HISTORY............................ 23

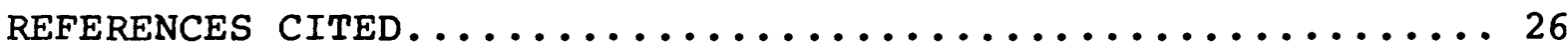

\section{ILLUSTRATIONS}

Figure 1. Index map of western Saudi Arabia showing location of the Jabal Umm Himar area......... 3

2. Geologic map of the Jabal Umm Himar area showing fossil and sample localities......... 5

3. Stratigraphic sections measured at vertebrate fossil localities in the Jabal Umm Himar

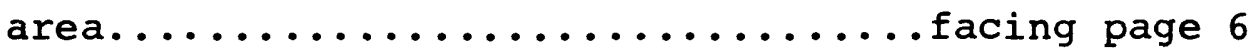

4. Composite stratigraphic columnar section of the Umm Himar formation................... 7

5. Ternary diagram (CaO-MgO-SiO $\left.{ }_{2}\right)$ showing composition of dolomitic limestone from upper member of the Umm Himar formation....... 12

\section{TABLES}

Table 1. Chemical analyses for $\mathrm{Fe}_{2} \mathrm{O}_{3}$ and $\mathrm{FeO}$ and semiquantitative analyses for other elements

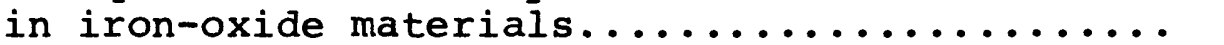

2. Partial chemical analyses, in percent, for major elements of samples from the dolomite member of the Umm Himar formation.................11

3. List of vertebrate fossils from the Jabal Umm Himar sample localities................. 16

4. Temporal ranges of the vertebrate fossils from Jabal Umm Himar...................... 20 


\section{PALEOCENE VERTEBRATES FROM COASTAL DEPOSITS IN THE HARRAT HADAN AREA, AT TAIF REGION, KINGDOM OF SAUDI ARABIA}

\section{by}

Cary T. Madden $1 /$, Ibne Mohammed Naqvi, Frank C. Whitmore, Jr. 2 /, Dwight L. Schmidt $\underline{3}$ /, Wann Langston, Jr. $4 /$, and Roger C. Wood $\underline{5}$

\section{ABSTRACT}

Fossil vertebrates collected from 17 localities at Jabal Umm Himar, near Turabah, Southern Hijaz province, Saudi Arabia, are the first Paleocene vertebrate fauna known from the Arabian Peninsula. The fossils are from a mudstone, 2 to $3 \mathrm{~m}$ thick, in the Umm Himar formation. This formation, about $20 \mathrm{~m}$ thick, consists of three members: a basal ferruginous mudstone, interbedded mudstone and shale, and a dolomitic limestone. The Umm Himar formation is underlain by Nubian-like quartzose sandstone, which overlies Precambrian rocks. The formation is overlain by the Harrat Hadan flood basalt of latest oligocene and early Miocene age.

The vertebrates include goblin sharks (cf. Scapanorhyncus); sand sharks (Odontaspis macrota); nurse sharks (Ginglymostoma blackenhorni and G. maghrebianum); angel sharks (Squatina); eagle rays (Myliobatidae); catfish; a large lungfish (Ceratodus humei); very large, side-necked turtles (Pelomedusidae); and primitive crocodilians (cf. Dyrosaurus). The Paleocene age determination for the fauna is based upon first-and last-appearance data: the first appearances of odontaspis macrota, Ginglymostoma blackenhorni, G. maghrebianum, and catfish are during the Paleocene; the last appearance of Ceratodus and African Scapanorhyncus are during the same epoch. The association of Ginglymostoma blackenhorni and Ceratodus humei suggests a late early or early late Paleocene age correlating to the late Danian or early Thanetien of Europe.

The paleoenvironment of Jabal Umm Himar was estuarine. The presence of a coastal environment indicates that at least a shallow seaway must have existed in the At Taif region during the earliest Tertiary.

1/ University of Colorado Museum, Boulder, Colorado 80309

2/ U. S. Geological Survey, Washington, D. C. 20244

$\overline{3} /$ U. S. Geological Survey, Denver, Colorado 80225

4/ Balcones Research Center, Austin, Texas 78758

5/ Stockton State College, Pomona, New Jersey 08240 


\section{INTRODUCTION}

Jabal Umm Himar is a large hill at lat $21^{\circ} 10^{\prime} \mathrm{N}$. and long $41^{\circ} 25^{\prime}$ E., $200 \mathrm{~km}$ east of At Taif and $26 \mathrm{~km}$ west of Turabah, in the central western part of Saudi Arabia (fig. 1). An unimproved desert road connecting At Taif and Turabah crosses the Jabal Umm Himar area (fig. 2) in the Jabal 'In quadrangle (Gonzalez, 1973). All parts of the area are readily accessible by 4-wheel-drive vehicle over the desert plain. The plain is at an altitude of about $1200 \mathrm{~m}$ and small hills rise 10 to $50 \mathrm{~m}$ above it. The conspicuous basalt plateau of Harrat Hadan rises nearly $200 \mathrm{~m}$ above the desert plain in the northern part of the Jabal Umm Himar area.

In 1971 two fossil vertebrae were collected by Schmidt from a small wadi at locality 1 (fig. 2), $3.5 \mathrm{~km}$ northeast of Jabal Umm Himar. In 1974, they were identified by Whitmore as representing a large member of the Mesosuchia, a widely distributed (Africa, Europe, Asia, North America, and South America) suborder of primitive crocodilians that originated in the Early Jurassic and became extinct in the middle Eocene. Additional surface material was collected during October, 1975, by Schmidt, T. H. Kiilsgaard, R. H. Blank, and M. E. Gettings.

The present preliminary report records the Paleocene vertebrates, stratigraphy, and environment of deposition in the Jabal Umm Himar area. This report is based upon paleontologic and geologic field investigations undertaken in July and August, 1976. The fossils described below constitute the first Paleocene vertebrate fauna known from the Arabian Peninsula.

\section{Previous investigations}

Brown and others (1963) mapped the region, including the Jabal Umm Himar area, as a part of the 1:500,000-scale map of the Southern Hijaz quadrangle. Baghanem (1972) described the geology of the Jabal Umm Himar area in a masters thesis for the South Dakota School of Mines and Technology. In 1970, Baghanem, then a geologist with the Directorate General of Mineral Resources, Kingdom of Saudi Arabia, collected fossils, including remains of turtles (Order Chelonia), from the Jabal Umm Himar area. His fossils were the first collected from the area.

Gonzalez (1973) mapped and described the Umm Himar deposits as a part of the 1:100,000-scale map and report of the Jabal

' In quadrangle.

\section{Acknowledgments}

Our field investigations were sponsored by the Directorate General of Mineral Resources (DGMR), Ministry of Petroleum and 


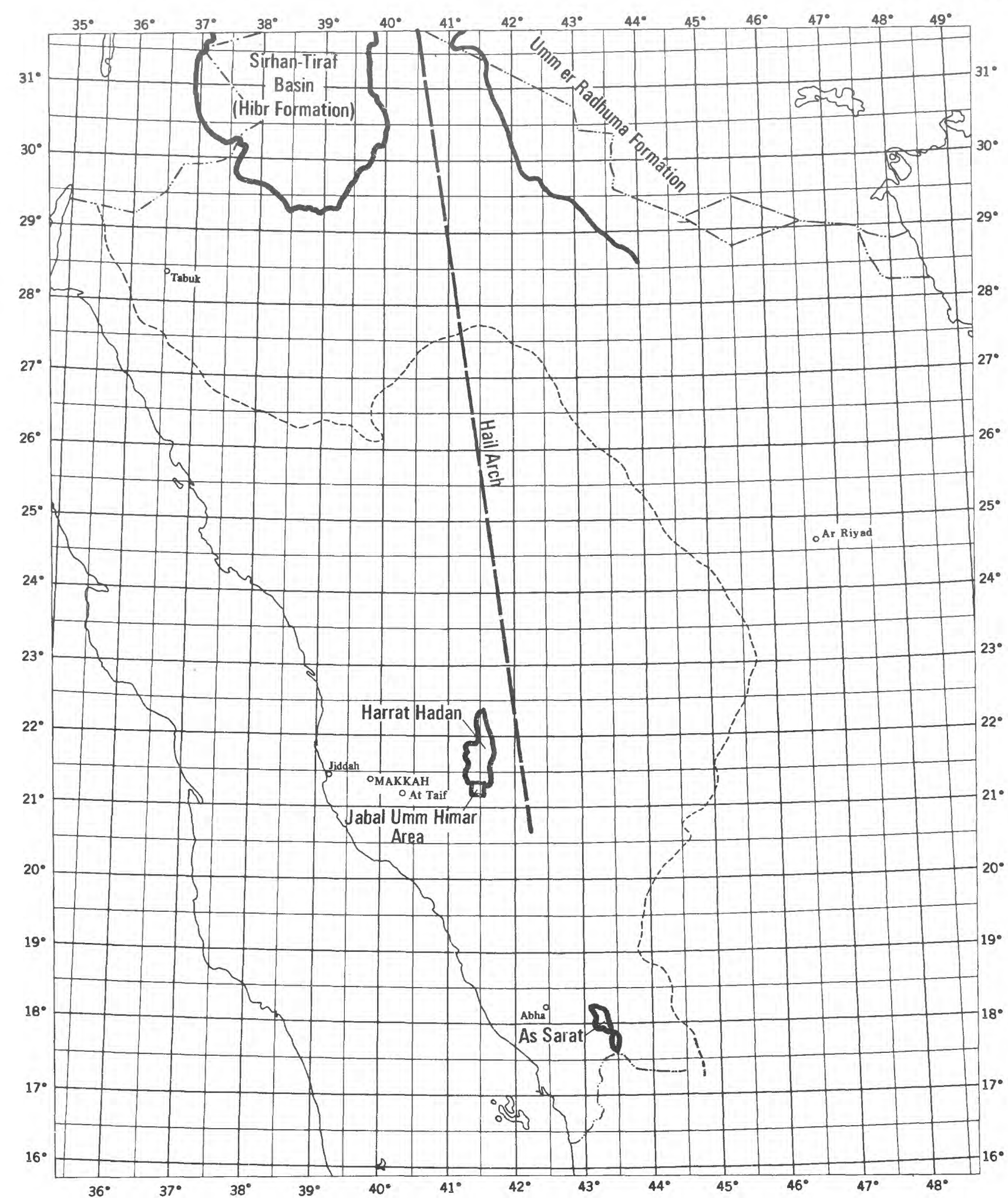

Figure 1.-Index map of western Saudi Arabia showing location of the Jabal Umm Himar area relative to the Hail Arch, the Sirhan-Tiraf Basin, and other geologic features. 


\section{EXPLANATION}

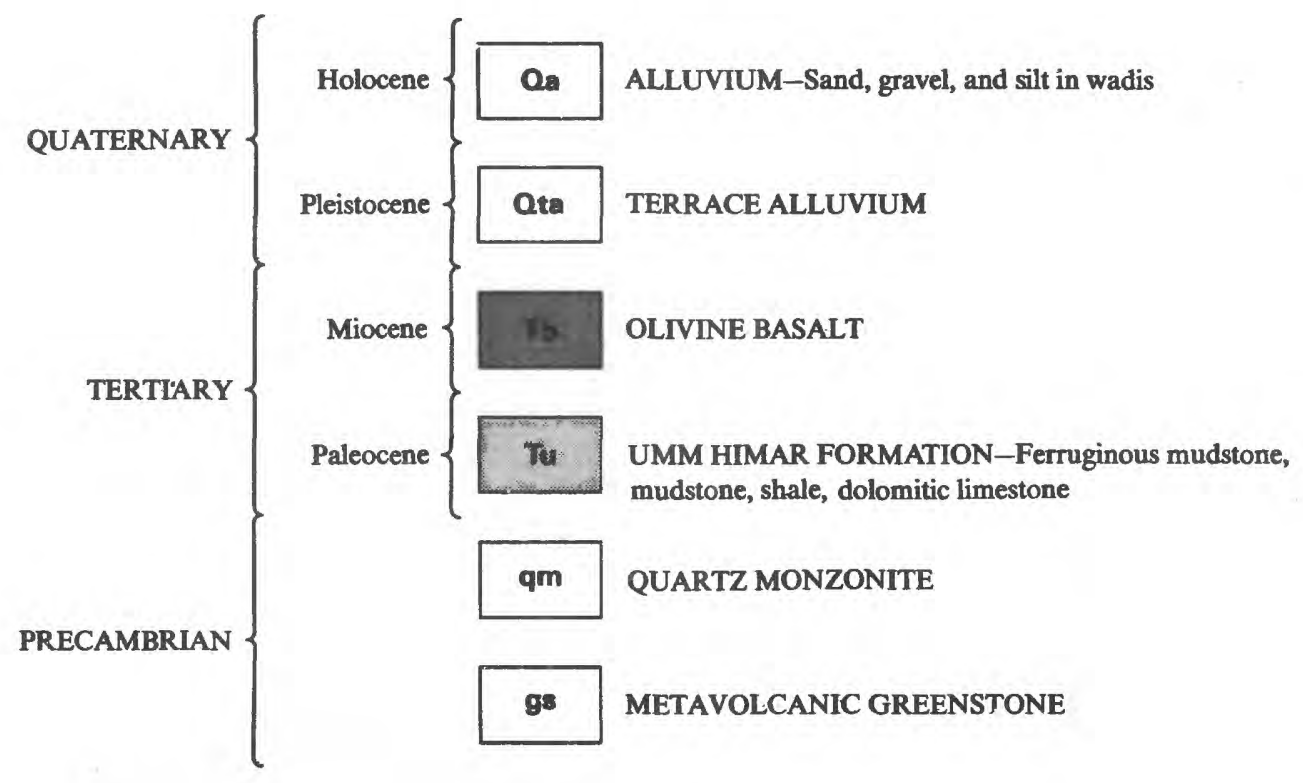

-3 Fossil localities

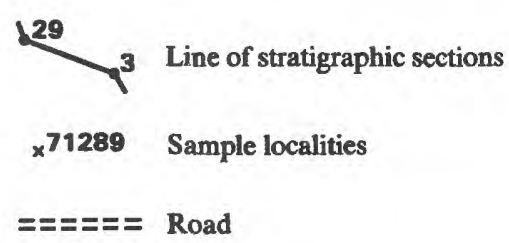




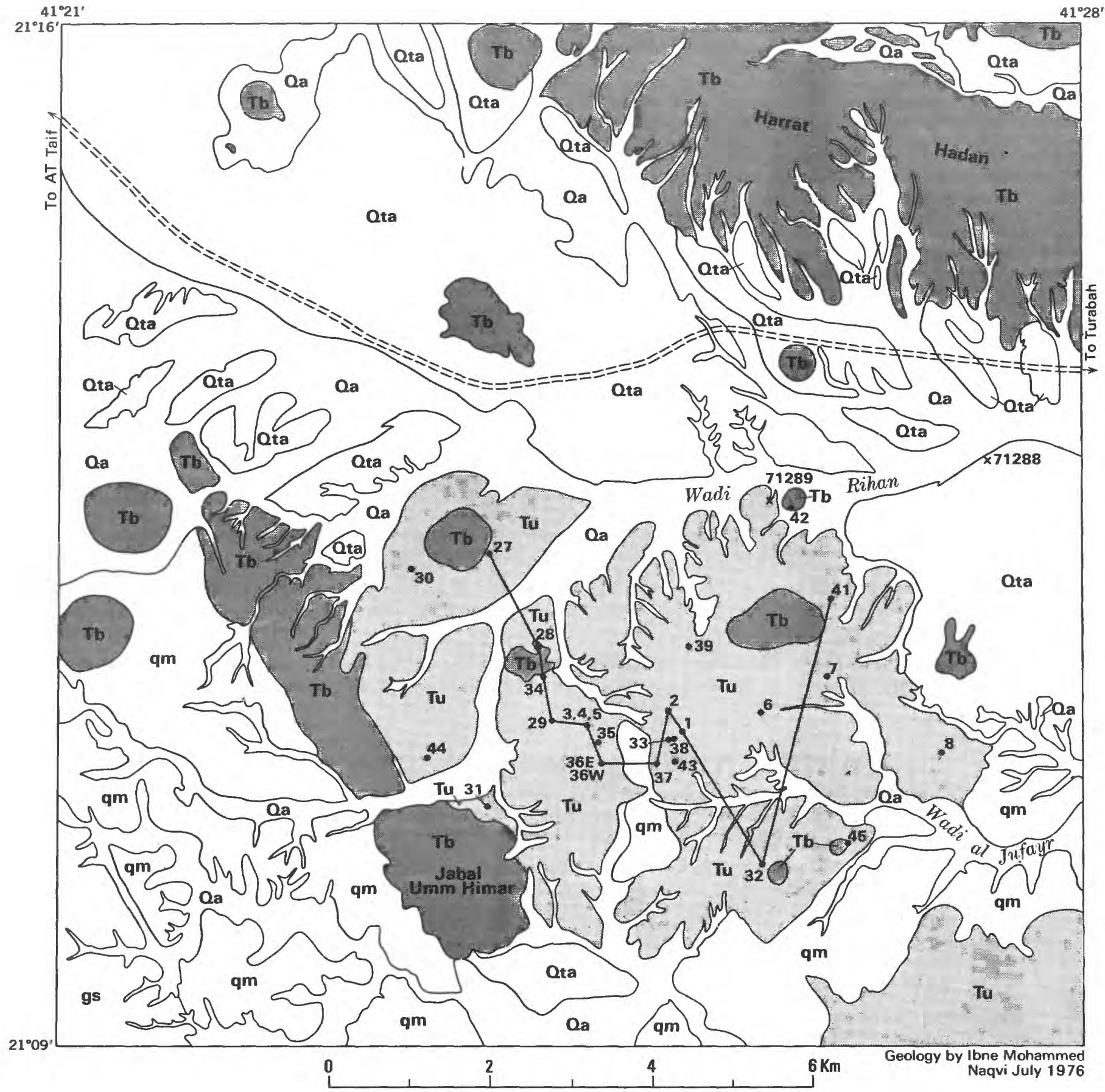

Figure 2. - Geologic map of the Jabal Umm Himar area showing fossil and sample localities. 
Mineral Resources, Kingdom of Saudi Arabia, under an agreement with the U. S. Geological Survey. We had helpful discussions about the paleontology and geology of Jabal Umm Himar with A. M. Baghanem, W. A. Berggren, Eric Buffetaut, G. F. Brown, Richard Estes, D. G. Hadley, J. H. Hanley, W. R. Hamilton, Nicholes Hotton III, Roman Karpoff, G. E. Meyer, T. H. Kiilsgaard, M. J. Novacek, R. W. Purdy, L. F. Rooney, I. G. Sohn, N. F. Sohl, V. A. Springer, W. R. Taylor, J. A. H. Van Couvering, S. H. Weitzman, and G. R. Zug. Participants in our various field parties were J. J. Matzko, T. H. Kiłlsgaard, Farah Warsama, Mohammed Mellah, and Mohammed Ali.

\section{STRATIGRAPHY}

The vertebrate fossils were collected at 17 localities in the Jabal Umm Himar area (fig. 2). Fossil bone fragments lie on slopes below--and within--a 2 to 3 m-thick fossiliferous mudstone of the Umm Himar formation herein named for Jabal Umm Himar. Stratigraphic sections were measured at each fossil locality and 12 of these sections are shown on figure 3 . The type section for the Umm Himar formation is at locality 3 (figs. 2 and 3 ). Tentative correlations between sedimentary units are shown on the diagram, figure 3. A composite columnar section, figure 4, shows the subdivision of the formation and characteristic thicknesses of its members. Outside the Jabal Umm Himar area, parts of the Umm Himar formation are exposed discontinuously over about $7,500 \mathrm{~km}^{2}$ around the Harrat Hadan plateau north of the Jabal Umm Himar area (Brown and others, 1963; Gonzalez, 1973; Baghdadi, 1977).

The Umm Himar formation consists of three members: a basal ferruginous mudstone, a middle fossiliferous interbedded mudstone and shale, and an upper dolomitic limestone. The formation is flat lying and about $22 \mathrm{~m}$ thick. It is underlain by Precambrian rocks consisting of metavolcanic greenstones and quartz monzonite (Gonzalez, 1973). In a few places, thin remnants of a quartzitic sandstone of the Khurma formation (Brown and others, 1963) lie between the Umm Himar formation and the Precambrian basement rocks.

The top of the Umm Himar formation is a slightly undulating erosion surface underlain by locally derived erosional debris less than $1 \mathrm{~m}$ thick. In many places this debris is a silicified breccia. Basalt flows of middle Tertiary age rest on the Umm Himar formation (Gonzalez, 1973).

\section{Khúrma formation}

Erosional remnants of white-to-tan, fluviatile quartzitic sandstone and quartz-pebble conglomerate, from 2 to $4 \mathrm{~m}$ thick, are exposed in several places in the Jabal Umm Himar area (for 


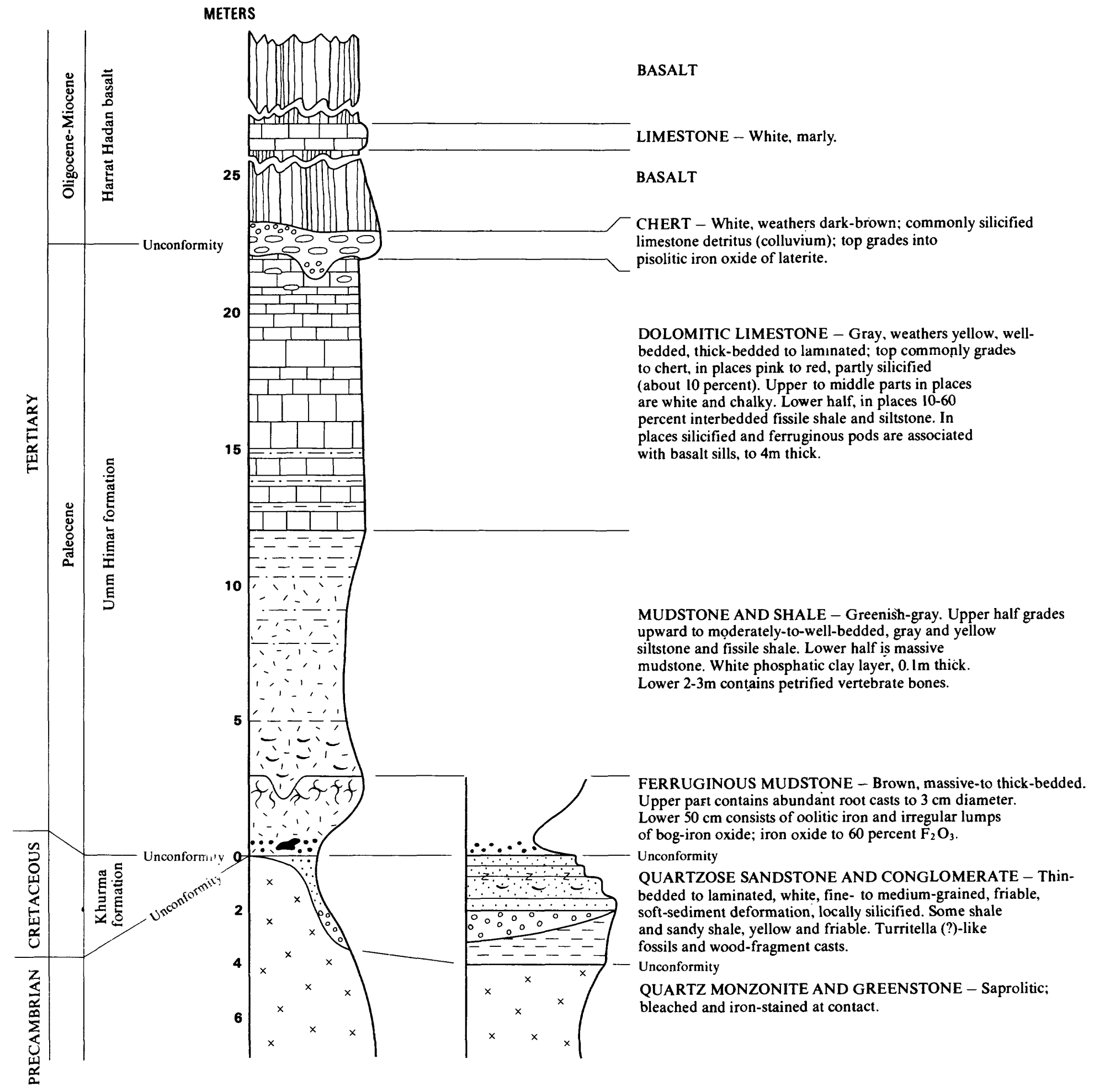

Figure 4. - Composite stratigraphic columnar section of the Umm Himar formation and overlying and underlying rocks in the Jabal Umm Himar area. 
example, locality 41 , fig. 2). The conglomerate lies directly on saprolitic quartz monzonite. Conspicuous crossbedding suggests a generally northerly transport direction (Baghanem, 1972). The rocks are commonly friable, but locally are well cemented by silica and iron oxide. The conglomerate contains rounded to subrounded pebbles that are as large as $1.2 \mathrm{~cm}$ in diameter and that average $0.6 \mathrm{~cm}$ across (Baghanem, 1972, p. 17). The sandstone appears to have been gently deformed and to lie with slight angular unconformity beneath the Umm Himar formation. The quartzitic facies contrasts sharply with the overlying mudstone of the Umm Himar formation. The sandstone is tentatively correlated with the Khurma formation that Brown and others (1963) mapped on the northeastern side of the Harrat Hadan.

\section{Umm Himar formation}

The basal member of the Umm Himar formation consists of red-brown oolitic iron oxide and mudstone from 2 to $4 \mathrm{~m}$ thick. In most places the member lies on saprolitic quartz monzonite of Precambrian age, but in a few places it lies unconformably on the Khurma formation.

The mudstone is massive to poorly bedded. It is characterized by oolitic iron oxide and irregular, fist-sized lumps of massive iron oxide, "bog iron". The oolites are from 0.3 to $2 \mathrm{~mm}$ in diameter and have nuclei of broken oolites, detrital grains, and fossil fragments (Baghanem, 1972). A bog iron specimen from locality 3 contains about 65.5 percent total iron as $\mathrm{Fe}_{2} \mathrm{O}_{3}$. A vertical channel sample through $50 \mathrm{~cm}$ of oolitic iron oxide contains about 61 percent total iron as $\mathrm{Fe}_{2} \mathrm{O}_{3}$; whereas, a vertical channel sample through $1 \mathrm{~m}$ contains about 45 percent total iron as $\mathrm{Fe}_{2} \mathrm{O}_{3}$ (table 1). Interstital quartz, calcite, chlorite, and goethite fill the space between the goethitic oolites (Baghanem, 1972, p. 21). The upper part of the member is ferruginous mudstone containing abundant root casts, as much as $3 \mathrm{~cm}$ in diameter, filled with iron-oxide oolites.

The middle member of the Umm Himar formation is greenishgray mudstone and tan shale from 5 to $10 \mathrm{~m}$ thick. The lower half is massive, thick-bedded mudstone, containing detritus, abundant montmorillonite, illite, and subordinate gypsum (Baghanem, 1972, p. 24). Fossil bones are locally abundant in the lower 2 to $3 \mathrm{~m}$. Most of the bones are disoriented fragments, but a few are articulated.

Carbonate fluorapatite and montmorillonite, according to $x$-ray diffraction analyses, comprise one or more conspicuously white beds, from 3 to $10 \mathrm{~cm}$ thick, in the lower half of the member. The $\mathrm{P}_{2} \mathrm{O}_{5}$ content of one bed is 5.96 percent (chemical analysis by DGMR-USGS Chemical Laboratory, Jiddah). Detrital grains, largely quartz, are sparse. Dispersed oolites, about 


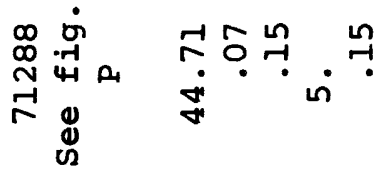

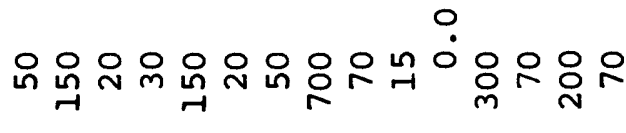

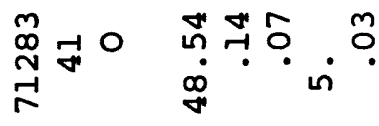

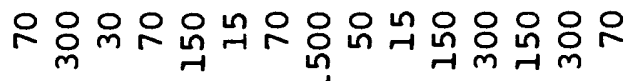

.

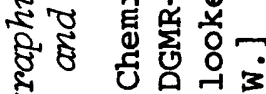

के०

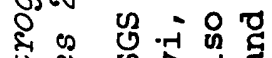

w 0 ⿹

\& ₹

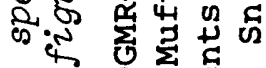

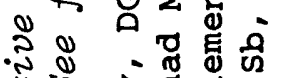

出

-

हु \&

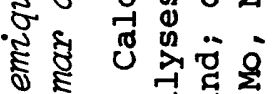

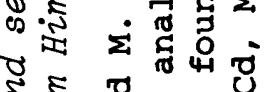

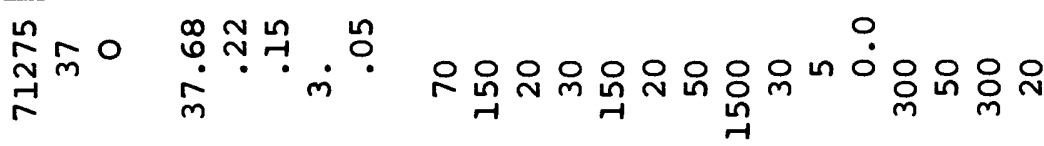

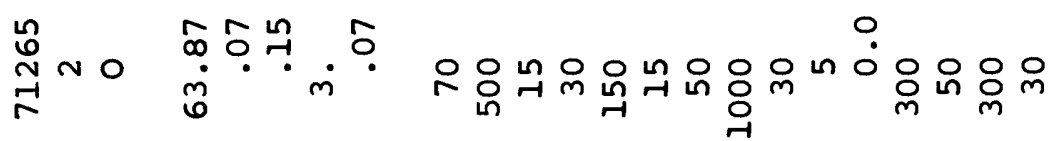

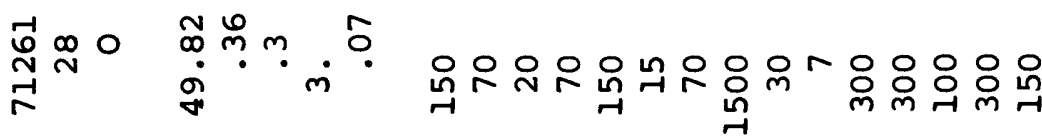

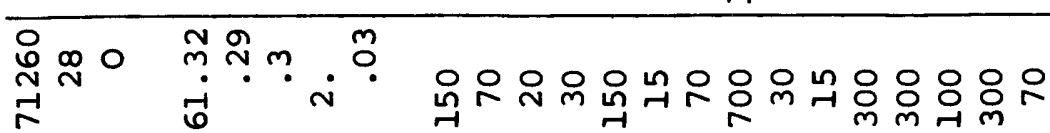

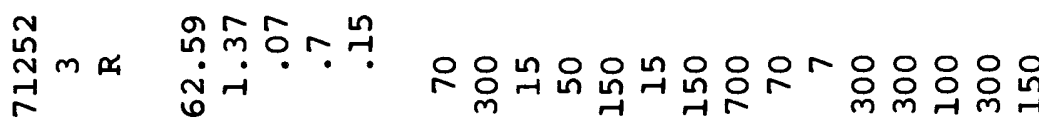

ON

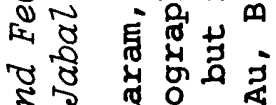

है

कू म्य में

每出

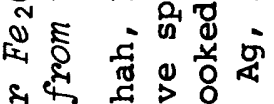

${ }^{\circ}$ क क

部

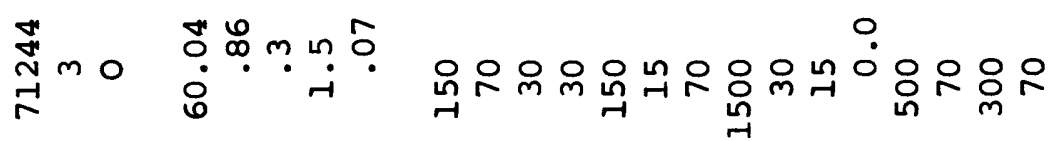

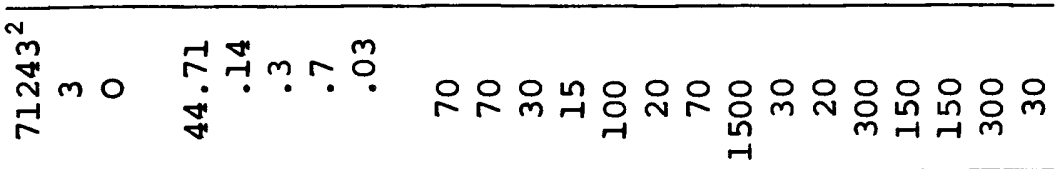

'马

क.

त)

है है

赵

>

ชै ต है

. हु \%

空

है

i.

क्ष

न

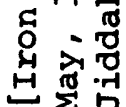

党

$\stackrel{m}{N}$

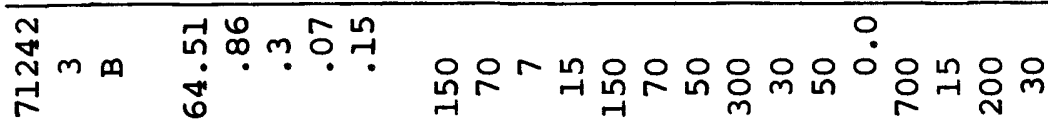

.

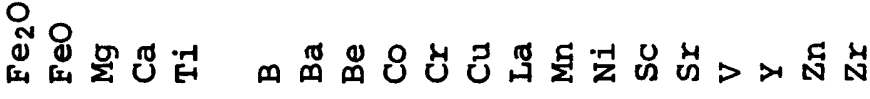
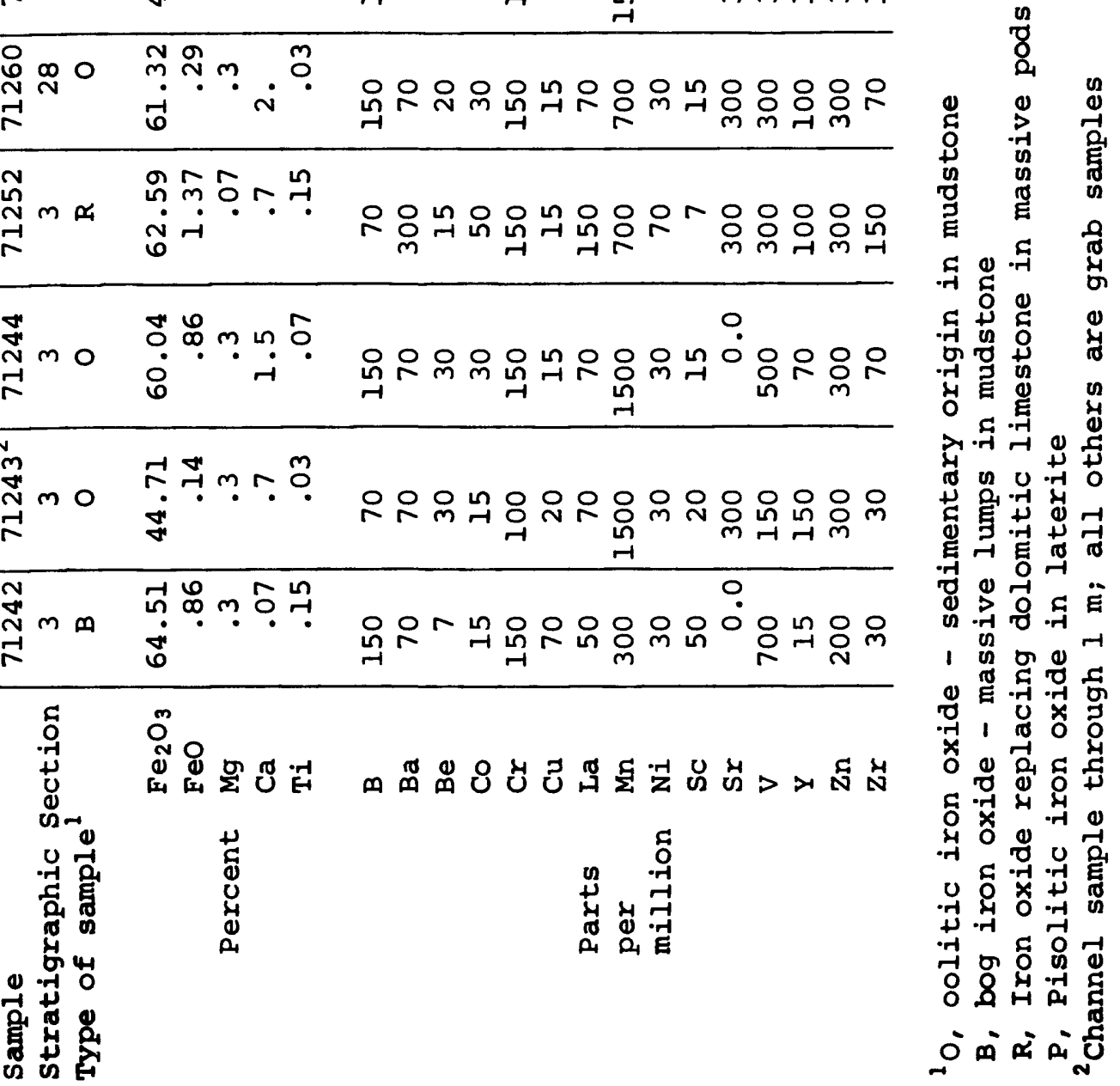
$1 \mathrm{~mm}$ in diameter, have well developed concentric structure and make up 20 percent of the sample. They consist largely of montmorillonite and carbonate fluorapatite. Near the top of the middle member, calcareous shale contains 1.37 percent $\mathrm{P}_{2} \mathrm{O}_{5}$ (vertical channel sample through $7 \mathrm{~m}$; no. 116218 , table 2) and suggests that possibly the entire middle member is slightly phosphatic.

The upper half of the member consists largely of interbedded siltstone and shale. Bedding becomes well developed to laminated near the top, where the shale is commonly highly fissile.

The upper member of the Umm Himar formation consists of gray, fine-grained dolomitic limestone that weathers yellowish tan. The rock is mostly well indurated but locally is chalky and white. The top is everywhere a gently undulating erosion surface. The preserved thickness of the member is commonly about $6 \mathrm{~m}$, and the maximum thickness is about $11 \mathrm{~m}$. Bedding ranges from thick bedded to laminar. At most places the lower contact with the shale is abrupt, but in some places the lower few meters consist of impure to silty limestone, or of interbedded limestone and shale. Fossil invertebrates and shell debris are poorly preserved locally. At least one bed of gastropod coquina, from 10 to $20 \mathrm{~cm}$ thick, lies near the upper part of the stratigraphic section. Baghanem (1972, p. 28) reports wellpreserved pelecypods and gastropods, as well as scattered quartz grains and carbonate oolites, and cross laminae. The composition of the carbonate rock is highly variable (table 2, fig. 5) and all samples but one are highly siliceous.

Small sills of basalt intrude the dolomitic limestone member and the mudstone and shale member at two localities (sections 3 and 34 , fig. 3). The basalt is related to the middle Tertiary basalt of the Harrat Hadan. The intrusive basalt locally deforms the bedding of the Umm Himar formation. This deformation and associated contact metamorphism are intense in places outside the Jabal Umm Himar area where larger sills and plugs of basalt intrude the formation. The intrusion causes local silicification and minor iron oxide replacement of the carbonate rock. One irregular pod of replacement iron oxide, $3 \mathrm{~m}$ long and $2 \mathrm{~m}$ wide, at locality 3, contains about 64 percent total iron as $\mathrm{Fe}_{2} \mathrm{O}_{3}$ (sample 71252, table 1). The $\mathrm{Fe}_{2} \mathrm{O}_{3}$ content of the carbonate rock is from 1.5 to 4 percent (table 2). The replacement iron contains 1.37 percent FeO, which is proportionally 2 to 7 times more abundant than the FeO content of the oolitic iron (table 1 ). The replacement iron was probably hydrothermally reworked from the sedimentary iron in the section during the emplacement of the intrusive basalt. 

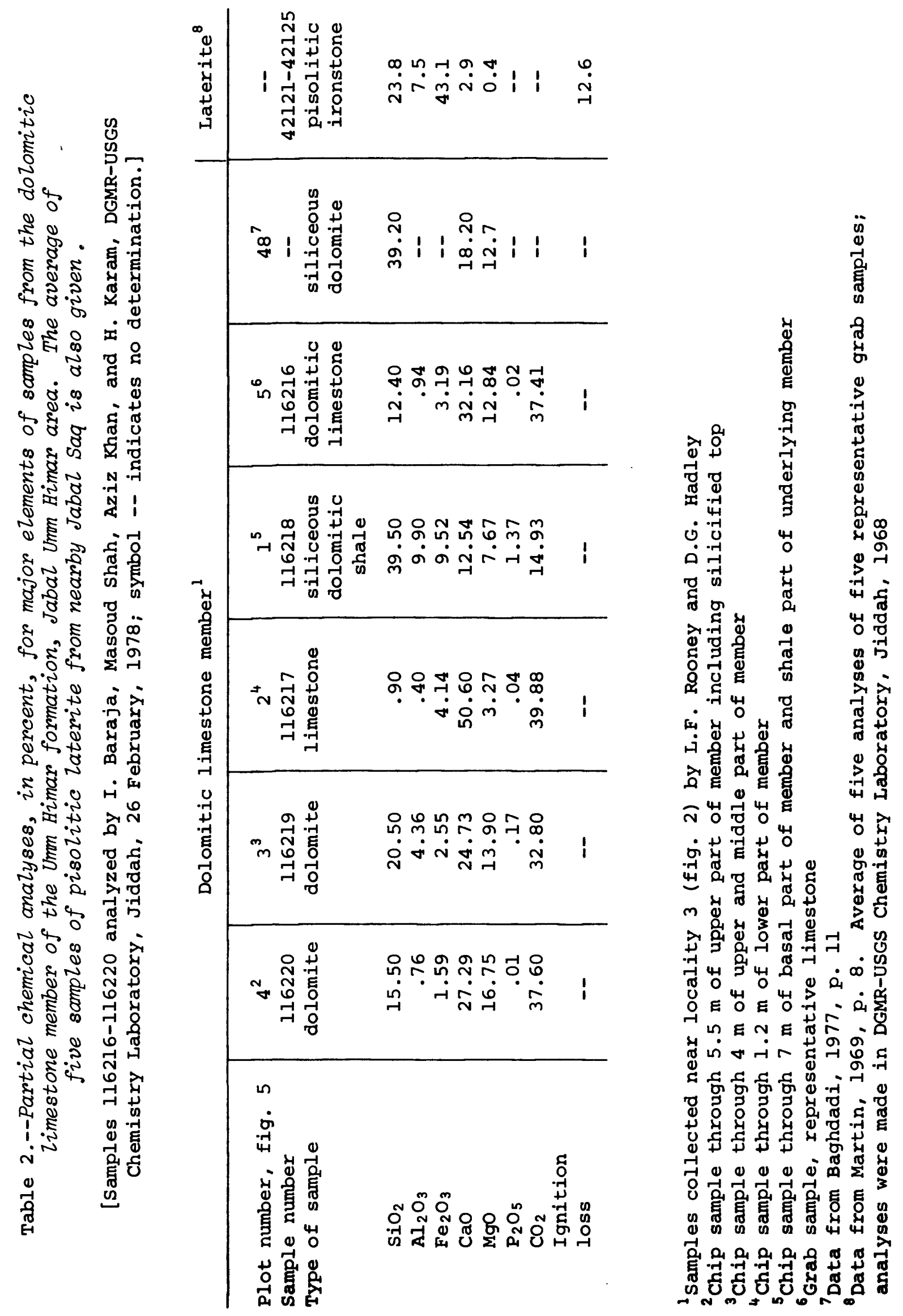


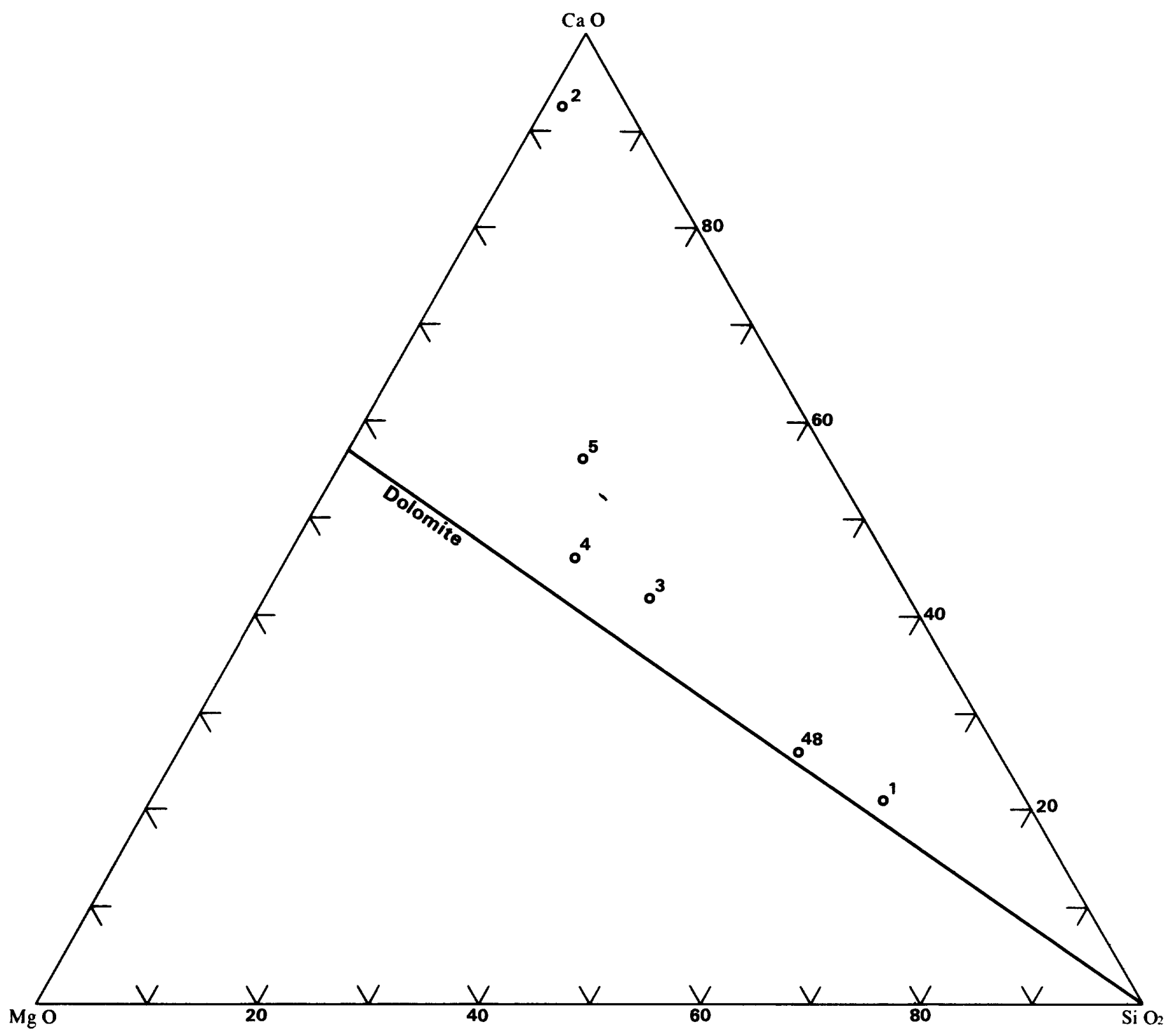

Figure 5. - Tertiary diagram $\left(\mathrm{CaO}-\mathrm{MgO}-\mathrm{SiO}_{2}\right)$ showing composition of dolomitic limestone from the upper member of the Umm Himar formation, Jabal Umm Himar area (see table 2). 


\section{Chert}

A siliceous breccia commonly forms the resistant top of the Umm Himar formation. The siliceous top of the dolomitic limestone member is nonconformable (fig. 3). This siliceous cap rock has protected and preserved the Umm Himar formation. The white cherty breccia weathers dark brown and is commonly from 0.5 to $1.5 \mathrm{~m}$ thick. It consists of silicified, angular fragments, from 0.5 to $3 \mathrm{~cm}$ across, of former carbonate including locally abundant shell debris, as well as other detritus. The siliceous breccia is probably silicified colluvium developed on a low-relief erosion surface cut on the Umm Himar dolomitic limestone. Remnants of iron oxide overlie the siliceous breccia in many places, especially where nearby outcrops of basalt have protected the iron oxide from erosion. Silicification extends downward into the Umm Himar dolomitic limestone; the gastropod coquina bed is especially well silicified. Baghanem (1972) describes two beds containing abundant gastropods and pelecypods that are replaced by silica near the top of the dolomitic limestone member. Brown and others (1963) mention a "silicified coquina of Melanoides-like fresh-water snails". It is unlikely that the chert is sedimentary silica related to the deposition of the Umm Himar formation. It is more probably that the silica is a product of soil processes and laterization following deposition of the Umm Himar formation.

\section{Laterite}

A pisolitic iron-oxide layer, in places several meters thick, lies above a jaspery substratum. This layer is always adjacent to--and overlain by--basalt, such that abundant basalt talus obscures the stratigraphic relations. In places it is inferred to overlie the dolomitic limestone member of the Umm Himar formation and hence probably lies on the silicified upper part of the formation. At Jabal Saq, $10 \mathrm{~km}$ west of the northwestern corner of the geologic map (fig. 2), a pisolitic iron-oxide layer of laterite (Martin, 1970, p. 11), about $5 \mathrm{~m}$ thick, lies on sandstone and quartz-pebble conglomerate (Khurma formation?) and is overlain by Tertiary basalt. The average composition of five samples from the Jabal Saq locality (Martin, 1969, p. 8) are given in table 2. Baghanem (1972, p. 36) refers to similar iron-oxide layers as "reworked ferric oxide deposits," some about $2 \mathrm{~m}$ thick. They rest on Precambrian rocks or on sandstone and are overlain by Tertiary basalt. A calcic phase in the "reworked deposits" (Baghanem, 1972, p. 37) is probably a carbonate cement deposited in the laterite by carbonate waters associated with the basalt eruptions.

The pisolitic iron-oxide layers are lateritic deposits formed prior to the deposition of the Tertiary basalt as described in the As Sarat area, $350 \mathrm{~km}$ south of Harrat Hadan (Overstreet and others, 1977). In the As Sarat area the laterite 
formed as late as Eocene and Oligocene and was covered by uppermost oligocene to lower Miocene basalt. A thick saprolite underlies the laterite in both the As Sarat and the Harrat Hadan areas.

\section{Harrat Hadan basalt}

Alkalic olivine basalt underlies the Harrat Hadan plateau, which rises nearly $200 \mathrm{~m}$ above the surrounding plain. Numerous buttes are erosional outliers of basalt flows; however, several buttes may be basalt feeders. These outliers of basalt rest upon the Umm Himar formation on all sides of the basalt plateau. The steep basalt scarps of the plateau and butte landforms are perpetuated by the underlying, less resistant Umm Himar beds. (The middle Tertiary basalt beneath its resistant cap rocks and resistant basalt talus slopes is highly saprolitic, and this deep-weathering product of the basalt also accounts in part for the steep basalt scarps.)

The Harrat Hadan basalt has been dated by the $\mathrm{K}-\mathrm{Ar}$, wholerock method at $15.8 \pm 1.8 \mathrm{~m} . \mathrm{y} .--$ sample $47021,16.2 \pm 1.5 \mathrm{~m} . \mathrm{y} .--$ sample 47023 (Gonzalez, 1973, p. 5), and $3.2 \pm 0.5 \mathrm{~m} . \mathrm{y} .--$ sample 47022 (G. F. Brown, oral commun., Feb. 1977). "Hornblende latite" in a dike complex at Jabal 'In may be a differentiate of the parent magma of the Harrat Hadan basalt. The latite has been dated $21.6 \pm 3.5 \mathrm{~m} \cdot \mathrm{Y}$. by the $\mathrm{K}-\mathrm{Ar}$, whole-rock method (Gonzalez, 1973, p. 5). The latite may be comparable to other subcrustal fractionation products of basaltic magma of middle Tertiary age such as 1) the felsic tuff on top of the basalt section overlying the Shumaysi formation in the Jiddah area (Al Shanti, 1966) and 2) the trachyte, dated $21.8 \mathrm{~m} . \mathrm{y}$. , that is intrusive into the As Sirat basalt (Coleman and others, 1977, p. 10 and 42).

The liarrat Hadan is similar geomorphically to high, erosional plateaus of basalt west and north of Medina and southeast of Khamis Mushayt. The latter is the As Sarat, which is well dated sequentially from its base to its erosional top from 29 to 24 m.y. (Brown, 1970; Coleman and others, 1977). The dates of the As Sirat basalt agree with the first stage opening of the Red Sea. The Harrat Hadan basalt therefore may be from 30 to about $22 \mathrm{~m} \cdot \mathrm{y}$. old. 
The fossil vertebrates from the 17 localities are named here the Umm Himar local fauna. These vertebrates include sand sharks (Odontaspis macrota); goblin sharks (cf. Scapanorhynchus sp.); nurse sharks (Ginglymostoma blackenhorni, G. maghrebianum); angel sharks (Squatina sp.); eagle rays (Family Myliobatidae); a very large pycnodont fish (Pycnodus? sp.); catfish; a large, primitive lungfish (Ceratodus humei); very large, side-necked turtles (Pelomedusidae); and primitive crocodilians (cf. Dyrosaurus sp.). (table 3). The most notable feature of this fauna is the combination of Mesozoic components (Squatina; Pycnodus?; Ceratodus humei; cf. Dyrosaurus) with earliest Cenozoic components (Odontaspis macrota, the two Ginglymostoma species, catfish). Such a combination is characteristic of the earliest Tertiary (Paleocene to middle Eocene) faunas of Africa (see Swinton, 1930; White, 1934; Arambourg, 1952; Arambourg and Joleaud, 1943; Cappetta, 1972; Priem, 1897; Stromer, 1905) and is to be expected of the Umm Himar fauna. Until the latest Oligocene, Arabia was a contiguous part of Africa (Brown, 1970); since then, with the opening of the Red sea and other plate movements, Arabia has been attached to Eurasia.

Galeoidea. Sharks are represented by odontaspis; cf. Scapanorhynchus; Ginglymostoma; and Squatina. The first three genera first appear in rocks of Cretaceous age in Europe, Africa, and(or) Asia, and of the four genera present only Scapanorhynchus does not occupy near-shore and estuarine habitats in coastal waters. Scapanorhynchus is at present restricted to the coasts of Portugal and Japan and may occur in Australian waters; odontaspis is found in the Atlantic and Pacific Oceans and the Mediterranean Sea; Ginglymostoma occurs in the Atlantic and Indian Oceans (Bigelow and Schroeder, 1948). Squatina has a nearly cosmopolitan distribution in tropical and temperate seas (White, 1934), and the earliest angel sharks are found in the Jurassic of Europe (Romer, 1966). The four genera present at Jabal Umm Himar arose in shallow seaways, probably in the Tethys. Squatina is present at localities 3, 36W, and 37 (fig. 2); odontaspis and Ginglymostoma at $36 \mathrm{~W}$ and 37 ; and scapanorhynchus only at $36 \mathrm{~W}$.

Myliobatidae. The remains of eagle rays were collected from 10 of the 17 localities. Like angel sharks, eagle rays are nearly cosmopolitan in their distribution in tropical and subtropical seas, and occupy near-shore and estuarine habitats in coastal waters, as do three of the four shark genera represented in the collections. Myliobatids first appear in the Late Cretaceous of Europe, Africa, and North and South America.

Pycnodontidae. This extinct family of holostean fish is represented by a jaw fragment from locality 1 . This specimen has one tooth from the inner dental row and parts of the alveoli 
Table 3.--List of vertebrate fossils from the Jabal Umm Himar sample localities

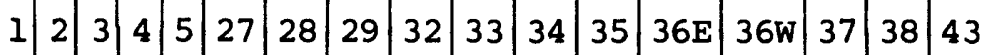

CHONDRICHTHYES

SELACHII 1,2

odontaspis macrota

cf. Scapanorhyncus sp.

Ginglymostoma maghrebianum

Ginglymostoma blackenhorni

Squatina sp.

BATOIDEA $^{2}, 3$

Myliobatidae

OSTEICHYTHYES

PYCNODONTIFORMES ${ }^{2}$

Pycnodus? sp. (very large)

SILURIFORMES ${ }^{4}$

?Ariidae

PERCIFORMES 5

DIPONI

Ceratodus humei ${ }^{3}$

REPTILIA

CHELONIA

Pelomedusidae sp. nov? ${ }^{6}$ (very large)

CROCODILA

cf. Dyroscourus sp. ${ }^{7}, 3$ $\begin{array}{lllllllll} & x & x & x & x & x & x & x\end{array}$ $\mathrm{x}$

$\mathrm{x} x$

$\mathrm{x}$

$\mathrm{x}$

$\mathrm{x}$

$\mathrm{x}$

$\mathrm{x} x \quad \mathrm{x}$

$\mathrm{x}$

5 Identified by J.A.H. Van Couvering ${ }^{6}$ Identified by R.C. Wood

${ }^{7}$ Identified by Wann Langston
1 Identified by R.W. Purdy

${ }^{2}$ Identified by C.T. Madden

${ }^{3}$ Identified by F.C. Whitmore, Jr.

${ }^{4}$ Identified by W.R. Taylor

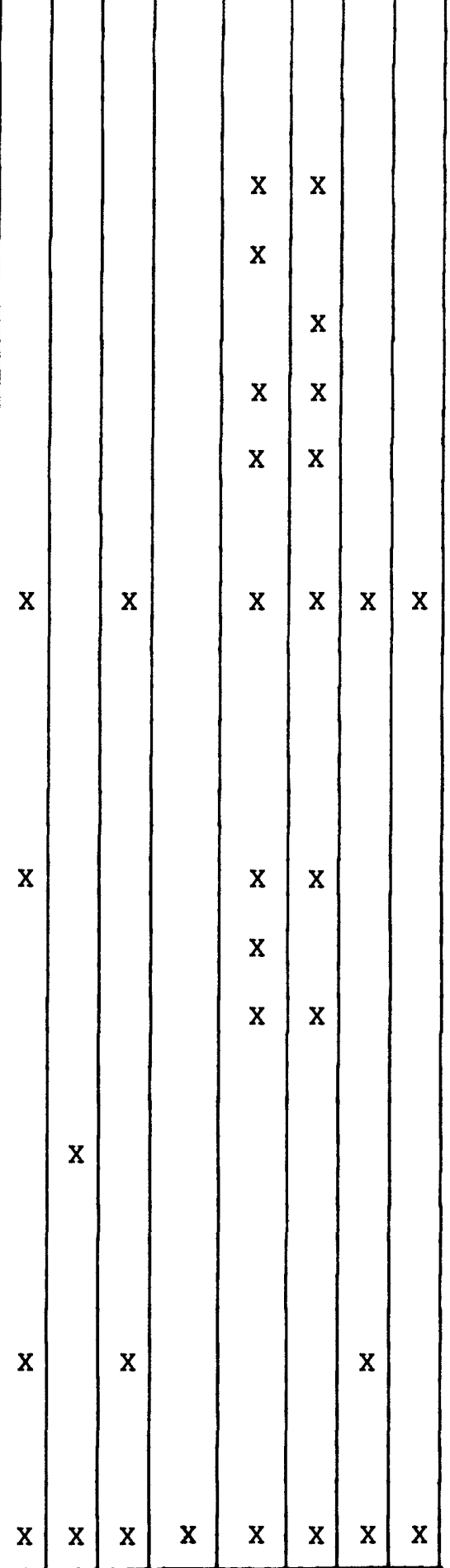


for two teeth from the medial row. The form represented must be the largest pycnodont known from Africa. The tooth preserved is $13.6 \mathrm{~mm}$ long and $34.7 \mathrm{~mm}$ wide. The morphology of the tooth, as well as that of the medial teeth (judging from their alveoli), and the positioning of the internal and medial tooth rows appear more like those in species of Pycnodous than in Palaeobalistrum., the only other species group of pycnodonts known from the early Tertiary of Africa. However, the material in hand appears too incomplete for a positive identification and the specimen is therefore questionably referred to Pycnodus.

Siluriformes. Catfish remains (spines) were recovered from four localities $(2,33,36 \mathrm{~W}, 37)$. These spines were identified by W. R. Taylor of the United States National Museum of Natural History. One of the spines from locality 36 is similar to pectoral spines in the Ariidae, a family that today inhabits the coastal waters of West Africa and the Red Sea. The earliest undoubted catfish are known from the Paleocene of Africa (see below).

Ceratodus humei. Lungfish are represented by a single tooth of a large Ceratodus from locality 34 . This specimen is identified as Ceratodus humei because of its low number of ridges and large size. It has four ridges and is $71 \mathrm{~mm}$ long and $45.5 \mathrm{~mm}$ wide. $C$. hume $i$ is a large lungfish endemic to Africa that first appeared in the Early Cretaceous and last appeared in the Paleocene (Tabaste, 1963; Cappetta, 1972). This species and a closely related form ( $C$. casieri) are the only members of Ceratodus to survive into the Tertiary. $C$. hume $i$ was widely distributed. It is known from both North and West Africa (Priem, 1914; Weiler, in Stromer and Weiler, 1930; Arambourg and Joleaud, 1943; Tabaste, 1963).

Pelomedusidae. Turtle remains, mostly shell fragments, are known from 15 of the 17 localities, but only those from 6 localities $(3,4,28,33,35,38)$ are identifiable. The remains from these localities represent only a single type, almost surely a pelomedusid or side-necked turtle. This determination is based upon the following characters, all of which are typical of pelomedusids: 1) lateral placement of two small bones, the mesoplastra, on the underside of the shell, 2) fusion of the pelvic girdle to the shell, and 3) the distinctive shape and arrangement of the neural bones that comprise the top of the shell. The Umm Himar turtle was very large, its shell being roughly comparable in size to that of the largest living pelomedusid Podocnemis expansa, from the Amazon and Orinoco Basins of South America. A badly fragmented and weathered shell at locality 33 measured some $900 \mathrm{~mm}$ in length. 
Modern pelomedusids are confined to South America, Madagascar, and sub-Saharan Africa. However, this group's fossil record demonstrates that they were much more widely distributed during the Late Cretaceous and early Tertiary. Fossil pelomedusids are known from the Atlantic coastal plain of the United States and Europe, the Pako-Indian subcontinent, North Africa, sub-Saharan Africa, and South America. The Arabian form partially bridges the geographic gap between pelomedusids known from North Africa and the Pako-Indian subcontinent. The Umm Himar species was probably essentially aquatic, judging from the flattening of its shells.

\section{cf. Dyrosaurus sp. Crocodilian remains occur in varying} abundance at 15 localities. All are from a large species of Mesosuchia, an extinct suborder characterized principally by primitive palatal construction and slightly concave ends on the vertebrae. All specimens are tentatively assigned to the genus Dyrosaurus Pomel. The material includes two skeletons: a fairly complete skeleton with an estimated length in excess of $4.5 \mathrm{~m}$, from locality 37, and a partial skeleton from locality 33. Indications of relatively small individuals are also present. Dyrosaurus is a genus endemic to Africa during the upper Cretaceous (equivalent to Maestrichtian) to the lower Eocene (equivalent to Ypresian). The Family Dyrosauridae, which contains one or more additional genera, ranges from the Upper Cretaceous to the middle Eocene, and has been reported from North and South America and Asia (Pakistan) as well as from Africa (Buffetaut, 1976b). During excavation, small and large smooth rounded pebbles and cobbles of quartzite were found near the crocodile skeleton at locality 37. Quartzite rocks are not indigenous to the fossil bed and these may have been brought in as gastroliths by the animal. The functional significance of these "gizzard stones" in crocodilians is conjectural, but existing species are known to ingest stones, which may aid in digestion or serve as hydrostatic ballast.

\section{AGE}

The Jabal Umm Himar local fauna is of Paleocene age. This determination is based upon first and last appearance data for the sand sharks Odontaspis macrota, the nurse sharks Ginglymostoma blackenhorni and G. maghrebianum, the lungfish Ceratodus, and catfish. The first appearance in the fossil record of odontaspis macrota, the two Ginglymostoma species, and catfish (Family Bagridae) are in the Paleocene (White, 1934; Arambourg, 1952; Cappetta, 1972, respectively). The last appearances in the record of Ceratodus and African Scapanorhynchus are in the same epoch (Tabaste, 1963; Romer, 1966). The association of Ginglymostoma blackenhorni and Ceratodus humei suggests a late early or early late Paleocene age; such an age would correlate 
with the late Danian or early Thanetien of Europe. G. blackenhorni first appears in the last half of the Paleocene (Arambourg, 1952). Ceratodus humei last appears in the first half of the Paleocene ("Montian" or Danian here, following Berggren, 1971). This Ceratodus is present in two early paleocene faunas from Mali, Cheit Keini, and In Farghas (Tabaste, 1963, table 4). However, the Ceratodus of the late Paleocene of Africa is not $C$. humei but $C$. casieri. This species is known from deposits in the Iullemmeden Basin of Nigeria, which correlate with those of the Thanetien (Cappetta, 1972). R. C. Wood reports that comparisons of the Umm Himar side-necked turtles with various North African and Indian subcontinent pelomedusids suggest an earliest TertiaryPaleocene or Eocene age. Buffetaut (written commun., 1977) has concluded that the Umm Himar fauna is probably of Paleocene age.

If the fauna is not Paleocene in age, it can be no older than Late Cretaceous and no younger than middle Eocene, based upon first and last appearance data. The first appearances in the fossil record of eagle rays, pelomedusid turtles, and the primitive crocodilians of the Family Dyrosauridae are in the late Cretaceous (Romer, 1966; R. C. Wood, written commun.; Gemmellaro, 1921; Deperet and Russo, 1924, 1925; Déperet and Savorin, 1925, 1927). The last appearances of dyrosaurids and pycnodont fish (Pycnodus) in Africa are in the middle Eocene (Arambourg, 1952; Arambourg and Joleaud, 1943; Priem, 1897; Stromer, 1905), although the genus Dyrosaurus is not surely known later than the early Eocene. The temporal ranges of the Umm Himar vertebrates are given in table 4 .

\section{PALEOENVIRONMENT}

The environment of Jabal Umm Himar during the Paleocene was estuarine or lagoonal; the climate was either tropical or subtropical, but probably seasonally arid in the nearby interior. These reconstructions are based upon the presence of certain vertebrates, their fossilized condition, and the type of sediments in which they were deposited.

Nearly all of the shark and ray genera found at Jabal Umm Himar occupy salt water and brackish water habitats in modern seas and oceans. The most notable features of this faunule, from a paleoenvironmental viewpoint, are the presence of nearshore forms and the virtual absence of pelagic ones. Scapanorhynchus is the only habitually pelagic form represented. This genus is present in all known pelagic Cretaceous fish faunas (Slaughter and Thurmond, 1974). Odontaspis, Ginglymostoma, and myliobatids (Myliobatis, Rhinopteral occupy coastal habitats, either near-shore or estuarine; all of these fish are most abundant in shallow waters (Bigelow and Schroeder, 1948, 1953). The presence of Squatina in the faunule provides some strength to the interpretation of the depositional environment, though by themselves these sharks are 


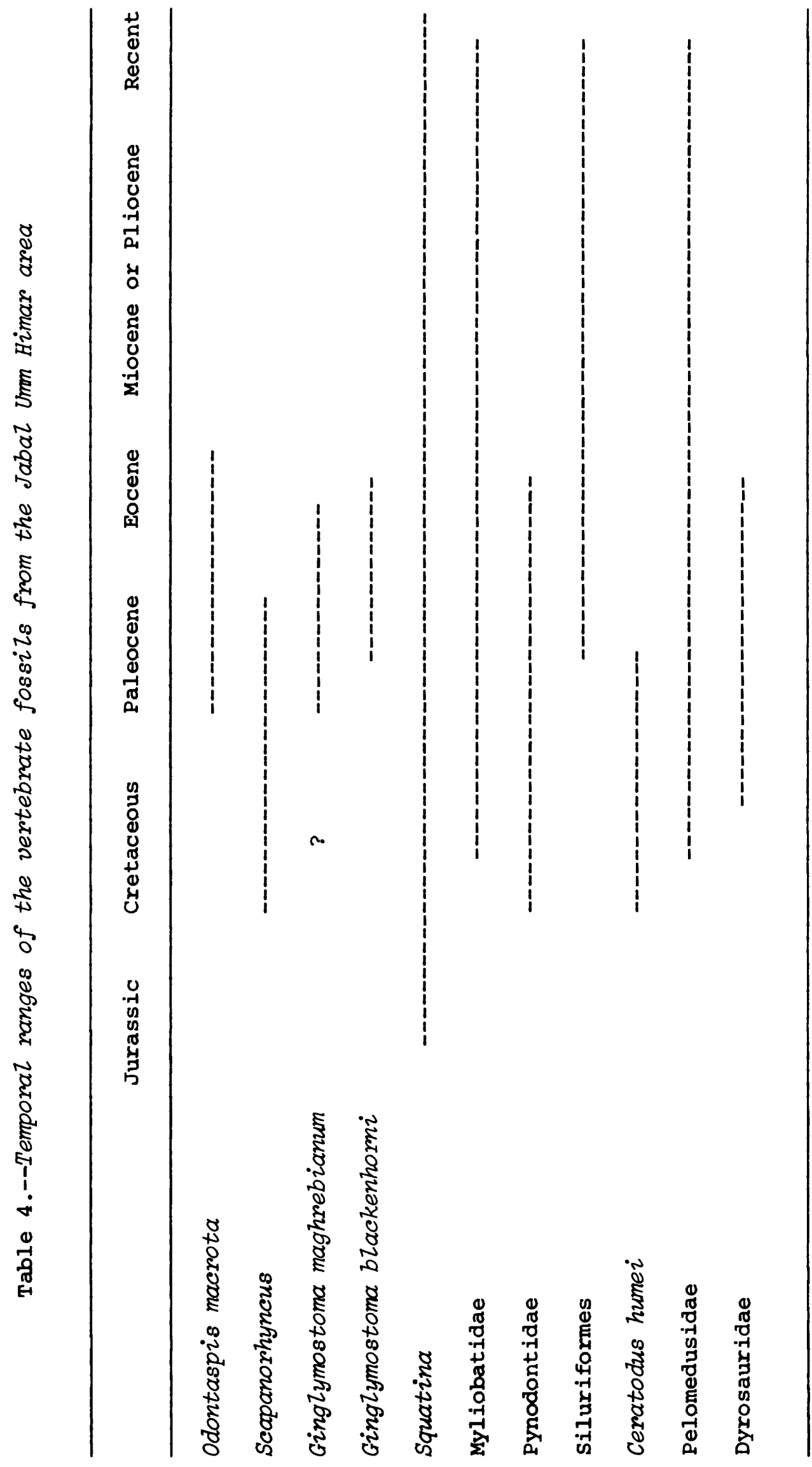


not useful; most modern angel sharks occupy coastal habitats and are most abundant in shallow waters, but they infrequently occupy pelagic habitats (see Bigelow and Schroeder, 1948). The presence of Ginglymostoma indicates a tropical or subtropical environment because these sharks at present inhabit only tropical and subtropical seas and oceans.

Like the sharks and rays from Jabal Umm Himar, dyrosaurs are commonly found in shallow marine sediments that are indicative of near-shore and estuarine environments (Buffetaut, 1976a; Swinton, 1930; White, 1934). An occurrence of dyrosaurs in fresh water sediments is reported from the Eocene of Pakistan (Buffetaut, $1976 b)$.

The fossil bed is composed of shallow-water deposits, either lagoonal or estuarine, that are poorly sorted and poorly consolidated. Such deposits indicate a low energy environment, one with little or only gentle current action. The partly articulated condition of the crocodile skeletons at localities 33 and 37 supports this observation. Abundant iron oolites and root casts in the bed immediately below the fossil bed suggest a lagoonal marsh in which tides provided the agitation for oolitic growth.

The lungfish Ceratodus humei indicates a probable seasonally arid climate, at least for the nearby interior. Most modern lungfish, namely species of African Protopterus and South American Lepidosiren, inhabit shallow, temporary bodies of fresh water in seasonally arid climates. They are able to survive in such climates by burrowing into the bottom mud and aestivating (undergoing suspended animation) during dry seasons. The single specimen of the lungfish, $C$. humei, was probably transported to the Umm Himar deposit from a fresh water habitat in the nearby interior. Modern lungfish inhabit fresh water exclusively.

Clams from near the top of the Umm Himar formation were identified by N. F. Sohl and E. G. Kauffman (written commun., 1975) and J. H. Hanley (written commun., 1977) as Brachidontes and a Corbicula-like form. The association of these two molluscs is indicative of a brackish water environment. Deposits of this marginal marine environment are presently exposed over an area of some $60 \mathrm{~km}$ by $120 \mathrm{~km}$.

The deposition of oolitic iron oxide in the Jabal Umm Himar area also suggests a tropical environment. In the Lake chad Region today, which can be used as a modern analog (Lemoalle and Dupont, 1973), iron is transported from a tropical zone of lateritic soil to a saline environment at Lake Chad where iron is deposited as oolites. In Lake chad the water salinity is a result of an arid climate, but at Jabal Umm Himar the depositional salinity was provided by the proximity of the sea and aridity need not be 
implied by evidence of the iron oolites. Kaolinite is the characteristic product of tropical weathering. Colloidal and(or) absorbed iron and kaolinite are transported in acid river water. On entering brackish or saline water, the solution becomes basic and the kaolinite is converted to montmorillonite (the common clay in the Umm Himar deposits) and reactive iron is precipitated with silica in the form of oolites.

At Jabal Umm Himar a tropical environment and tropical weathering persisted after the deposition of the Umm Himar formation. This is indicated by the development of a laterite upon the Umm Himar deposits. The siliceous part of the soil profile is best preserved, but in places, remnants of the pisolitic iron oxide (upper part of the profile) are preserved and overlain by the Harrat Hadan basalt.

In the southern Arabian Shield, laterite is well preserved beneath the basalt flows of the As Sarat; the lowest flows are dated about late Oligocene, (Coleman and others, 1977). The lower basalt flows themselves are partly laterized (overstreet and others, 1977, p. 10) and the equivalent Yemen Volcanics (formerly Trap Series) to the south contains intercalated paleosols (Overstreet and others, 1977, p. 10; Grolier and Overstreet, 1978).

It is interesting to note that the four types of iron oxide deposits in the Jabal Umm Himar area probably have a common initial source of iron that is associated with tropical weathering. This is suggested by similar minor-element abundances for all the iron types (semiquantitative spectrographic analyses, table 1). The pisolitic iron of the laterite was a direct product of tropical weathering of the Umm Himar deposits. The oolitic iron and the "bog iron" . deposited in the basal part of the Umm Himar formation, resulted from iron transported from nearby lateritic soils. The replacement iron in the dolomitic limestone member probably was hydrothermally reworked iron from the other three deposits; the hot intrusive basalt of Harrat Hadan basalt age heated interstitial water in the Umm Himar sediments and.through convection the hot water transported and deposited iron in the dolomitic limestone.

\section{OTHER VERTEBRATE FOSSILS FROM ARABIA}

The vertebrate fossils from Jabal Umm Himar are the first Paleocene vertebrate fauna known from the Arabian Peninsula. The Umm Himar vertebrate fauna is the eleventh collection of vertebrates reported from Saudi Arabia. These collections range in age from the Jurassic to the late Miocene.

F. C. Whitmore, Jr. (written commun., 1976) has identified two vertebrae collected by P. L. Binda (formerly DGMR; now at King 
Abdulaziz University, Jiddah) from the Jurassic Hanifa limestone southeast of Jizan as belonging to a primitive (mesosuchian) crocodile.

Karpoff (1957) reported that fossils collected from the Usfan formation, near Jiddah, include sharks ("squales"); he (written commun., 1977) reports that these forms represent galeoids.

R. Meyer (written commun., 1975) has identified a fish fauna of Oligocene or Neogene age and of modern African or Asian affinities from the Ad Darb area, Jizan region. Dunkle (in Brown, 1970) identified a similar fauna from the same region.

Powers and others (1966, p. D97) reported the first fossil vertebrates from eastern Arabia. These comprised indeterminate sharks from the Hadrukh Formation of probable early Miocene age and indeterminate vertebrates from the Dam Formation of earlier middle Miocene age. Later, Tleel (1973) reported fossil mammals from the latter formation, near Dhahran; his report is the first published reference to Tertiary mammals. More recently, Hamilton and others (1978) recorded two faunas from the Dam Formation: 1) The Jabal Midra ash-Shamali fauna includes a fish (Lates), turtle, rabbit (Order Lagomorpha), cricetodon rodent (cf. Cricetodon atlasi), an indeterminate dipodid rodent, and small and mediumsized species of bovids (Family Bovidae). 2) The Ad Dabtiyah fauna is the largest and most diversified fauna known so far from Arabia; it consists of fish, turtle, crocodile, two new but indeterminate species of dryopithecine apes (see also Andrews and others, 1978), an indeterminate carnivore, indeterminate rodents, a geniohyid hyracoid (cf. Pachyhyrax championi), a shovel-tusked gomphotheriid proboscidean (?Amebelodon filholi), two rhinoceroses (Brachypotherium sp. and Dicerorhinus or Aceratherium sp.), two indeterminate species of pigs, a water chevirotan (Dorcatherium cf. Liberensis), an indeterminate giraffe, and an indeterminate boselaphine bovid.

Brown (oral comm., 1977) reports that some years ago an advanced horse fossil of late Tertiary age was collected from Al Hufuf Oasis. Advanced horses first appeared in the old World during the late Miocene. This biochronologic datum provides a maximum age determination for the Al Hufuf sample.

\section{GEOLOGIC HISTORY}

Vertical movement on the central Arabian arch controlled erosion and sedimentation in central Arabia during the Paleozoic and Mesozoic (Powers and others, 1966, p. 103). During the middle Cretaceous southern Arabia was uplifted while northern Arabia continued to subside. The Hail arch first emerged during the Late Cretaceous along an axis trending north-northwest through the vicinity of Hail (fig. 1). The Aruma formation, Upper 
Cretaceous, consisting of sandstone and an upper phosphorite bed, shows distinct facies changes across the arch. By the Paleocene, during further uplift of the arch, a Mediterranean seaway was separated from the eastern seaway of the Arabian Gulf (Powers and others, 1966, p. 104). Paleocene deposition is represented by the lower Hibr formation of limestone and phosphorite beds in the Sirhan-Turayf basin of northwestern Arabia (Meissner and Ankary, 1972) and Jordan (Bender, 1975).

The Mediterranean seaway transgressed southward across Egypt and Upper Cretaceous and Paleocene marine deposits were deposited; maximum transgression in Egypt was during the late paleocene (Landenian) (Said, 1962, p. 144-5). Evidence of this marine transgression is not preserved in the sudan (Whiteman, 1971). Maximum southerly transgression of the seaway reached the vicinity of Jiddah where a marine limestone, the Usfan formation, was deposited during the late Paleocene(?) (Karpoff, 1957; Brown, 1970). The Usfan formation consists of, in ascending order, fossiliferous marine limestone, fine-grained sandstone with minor silty sandstone beds, glauconitic sandstone (approximately dated at $42.8+1.0$ and $55+1.2 \mathrm{~m} . \mathrm{y}$. by the $\mathrm{K}-\mathrm{Ar}$ whole-rock method), and chert (possiblȳ silicified mar1) (Brown, 1970). Brown and others (1963) report a phosphatic constituent in the Usfan. The maximum southerly transgression, the Jiddah embayment, extended more than $200 \mathrm{~km}$ east of Jiddah and to the east of Taif. A coastal area (strand line) existed in the vicinity of Harrat Hadan at the Jabal Umm Himar fossil locality. The embayment axis may have been in the present location of the Red Sea.

The eastern boundary of the Jiddah embayment was probably along a southerly extension of the Hail arch, and the southern embayment perhaps connected with the Paleocene Sirhan-Tiraf basin to the north. At Jabal Umm Himar, the Umm Himar formation, initially more than $22 \mathrm{~m}$ thick, was deposited during the middle Paleocene in a restricted lagoonal-estuarine environment.

In the Harrat Hadan area the Umm Himar formation is underlain by quartzose sandstone and quartz-pebble conglomerate of the Khurma formation (Brown and others, 1963). The Khurma formation is a mature fluviatile deposit of Nubian facies. The continental Khurma formation may be correlated with some part of the marine sandstone of the Aruma Formation that was deposited in the early Sirhan-Turaf basin in the northwestern part of Saudi Arabia. In Sudan the youngest Nubian Sandstone is middle Cretaceous (Turonian; Whiteman, 1971, p. 50). In Egypt the Nubian Sandstone underlies Cenomanian deposits (Said, 1962, p. 318).

After deposition of the Umm Himar formation, the sea receded from the Jiddah embayment. Slight erosion of the upper part of the formation resulted in a gently undulating surface covered by limestone colluvium. This debris was subsequently weathered to 
laterite in a semitropical or tropical climate both in Saudi Arabia (Overstreet and others, 1977) and in Sudan (Delany, 1954). Still later, much of the ferriferous part of the lateritic soil was eroded leaving the underlying silicic part of the soil profile. This resistant silicified soil zone, in addition to a low relief that was near sea level, accounts for the preservation of the thin Umm Himar formation for about $25 \mathrm{~m} . y$. until it was covered by the Harrat Hadan basalt.

The complete regression of the Paleocene sea by late early Eocene is well recorded in the Sinai, Gulf of Suez, and northern part of Egypt (Tromp, 1950, p. 386; Said, 1962, p. 145). A significant regional unconformity lies at the base of the middle Eocene in Egypt (Tromp, 1950, p. 386). Another broad but brief transgression and regression resulted in middle Eocene limestone deposition in Egypt. However, in the Gulf of Suez a continuous marine section of upper Eocene and oligocene indicates that some form of narrow proto-Red Sea trough existed (Tromp, 1950, p. 386). The Shumaysi formation of probable oligocene age and of mixed marine and continental facies (Al Shanti, 1966, p. 22) suggests a more extensive proto-Red Sea basin. The Shumaysi formation is conformably overlain by a thick section of basalt flows. Both were subsequently extensively block faulted during the Miocene, probably during the initial rise of the Red Sea Escarpment.

The basalt of the Harrat Hadan is alkalic and of latest oligocene to early Miocene age, despite the somewhat younger $\mathrm{K}-\mathrm{Ar}$ dates on the basalt. The earliest alkalic basalts around the Red Sea seem to be latest oligocene to early Miocene age. In Egypt, scattered but widespread thin basalt flows overlie fluviomarine sediments as young as late oligocene and are overlain by lower Miocene marine sediments well dated by fossils (Tromp, 1950, p. 390). Basal flows of the Ethiopian basalt series in southeastern Sudan have been dated at $33 \mathrm{~m} . \mathrm{y}$. old by the $\mathrm{K}$-Ar method (Grasty and others, 1963, p. 101) but this date is considered too old by Jones and Rex (1974). The basal basalt overlies laterite and contains interbeds of mudstone with plant fossils, $0.5 \mathrm{~m}$; marls with Melanoid fossils, $0.5 \mathrm{~m}$; limestone with crocodile, catfish, and wrasse fossils, $1 \mathrm{~m}$; and dolomite, $0.2 \mathrm{~m}$ (Delany, 1954, p. 16; Whiteman, 1971, p. 103). The Ethiopian basalt series in Ethiopia is dated at 27 to $23 \mathrm{~m} \cdot \mathrm{y}$. by Jones and $\operatorname{Rex}$ (1974), which corresponds well to the As Sirat basalt dates of 29 to 24 m.y. in southern Saudi Arabia, about $250 \mathrm{~km}$ east of the basalts in Sudan and Ethiopia (distance with Red Sea closed). In the Afar of Ethiopia the early volcanics are dated from latest oligocene to early Miocene (Mohr, 1975).

The Red Sea Escarpment was uplifted during the Miocene after the initiation of the first stage opening of the Red sea and after the extensive volcanism of alkalic basalt on the continental margins adjacent to the Red Sea. This rise of the Red sea Escarpment 
and the resultant elevation of the Harrat Hadan started the present erosion cycle at Harrat Hadan. The erosionally resistant laterite on the Umm Himar formation formed a lagging stripped surface adjacent to the receding basalt scarp of the Harrat Hadan plateau. The Harrat Hadan basalt was deeply weathered to saprolite during the Miocene and Pliocene, and the low erosional resistance of the saprolitic basalt greatly enhanced the stripping process and the development of the plateau landform. Erosion in the Harrat Hadan area was augmented during a second uplift of the Red Sea Escarpment sometime after the initiation of a secondstage opening of the Red sea after about $5 \mathrm{~m} \cdot \mathrm{y}$. ago. This second uplift has elevated the Umm Himar formation at Harrat Hadan about $1200 \mathrm{~m}$ above its Paleocene marine correlative, the Usfan formation, near Jiddah.

\section{REFERENCES CITED}

Al-Shanti, Ahmad, M.S., 1966, Oolitic iron ore deposits in Wadi Fatima between Jeddah and Mecca, Saudi Arabia: Saudi Arabian Directorate General of Mineral Resources Bulletin 2, 51 p.

Andrews, Peter, Hamilton, W.R., and Whybrow, P.J., 1978, Dryopithecines from the Miocene of Saudi Arabia: Nature, V. 274, no. 5668, p. 249-251.

Arambourg, Camille, 1952, Les vertébrés fossiles des gisements de phosphates (Maroc-Algérie-Tunisie): Service des Mines du Maroc; Rabat, Notes et Mémoires, 92, p. 1-372.

Arambourg, Camille, and Joleaud, L., 1943, Vertébrés fossiles du Bassin du Niger: Dir. Mines Bulletin A.O.F., Dakar, no. 7, p. 33-70.

Baghanem, A.M., 1972, Geology of the lake beds near Turabah, Saudi Arabia: M.S. Thesis, South Dakota School of Mines and Technology, Rapid City; see also: Saudi Arabian Directorate General of Mineral Resources, Open-File Report $488,59 \mathrm{p}$.

Baghdadi, A.J., 1977, Prospecting for limestone around Harrat Hadan: Bureau de Recherches Géologiques et Minières Saudi Arabian Mission Report 77 JED 26 , 13 p.

Bender, Friedrich, 1975, Geology of the Arabian Peninsula, Jordan: U.S. Geological Survey Professional Paper 560 I, 36 p.

Berggren, W.A., 1971, Tertiary boundaries and correlations; in Funnel, B.F., and Riedel, W.R., (eds.), The Micropaleontology of Oceans: Cambridge University Press, p. 693-809.

Bigelow, H.B., and Schroeder, W.C., 1948, Fishes of the western North Atlantic: Sears Foundation Marine Research, Memoir I, New Haven, Yale University, $576 \mathrm{p}$. 
, 1953, Fishes of the western North Atlantic: Sears

Foundation Marine Research, Memoir 2, New Haven, Yale University, $588 \mathrm{p}$.

Brown, G.F., 1970, Eastern margin of the Red sea and the coastal structures in Saudi Arabia: Royal Society of London Philosophical Transactions, Series A, v. 267, p. 75-87.

Brown, G.F., Jackson, R.O., Bogue, R.G., and Maclean, W.H., 1963, Geologic map of the Southern Hijaz quadrangle, Kingdom of Saudi Arabia: U.S. Geological Survey Miscellaneous Geologic Investigations Map I-210 A, scale I:500,000.

Buffetaut, Eric, 1976a, "Une nouvelle definition de la Famille des Dyrosauridae De Stefano, 1903 (Crocodylia, Mesosuchia) et ses conséquences: inclusion des genres Hyposaurus et Sokotosuchus dans les Dyrosauridae": Geobios, v. 9, fasc. 3, p. 333-336.

- 1976b, Sur la répartition géographique hors d'Afrique des Dyrosauridae, Crocodiliens mésosuchiens du Crétacé terminal et du Paléogène: Académie des Sciences (Paris), Comptes Rendus, Série D, tome 283, p. 487-490.

Cappetta, H., 1972, Les poissons crétacés et tertiaires du Bassin des Iullemmeden (République du Niger): Palaeovertebrata, v. 5, 179-251.

Coleman, R. G., Fleck, R, J., Hedge, C. E, , and Ghent, E. D, , 1977 , The volcanic rocks of southwest Saudf Arabla and the opening of the Red Sea: Saud1 Arabla Directorate General of Mineral Resources Bul1. 22, P. D1-D30.

Delany, F.M., 1954, Recent contributions to the geology of the Anglo-Egyptian Sudan: International Geological Congress, 19 th, Algiers, v. 20, p. 11-18.

Depéret, C., and Russo, P., 1924, Sur une faune sénonienne de Mosasauriens et de Crocodiliens à la base des couches phosphatées de Melgou (Maroc occidental): Académie des Sciences (Paris), Comptes Rendus, v. 178, p. 1666-1670.

, 1925, Les phosphates de Melgou (Maroc) et leur faune de Mosasauriens et de Crocodiliens: Société Géologique de France Bulletin, v. 25, p. 329-346.

Depéret, C., and Savorin, J., 1925, Sur la découverte d'une faune des vertébrés albiens à Timimoun (Sahara occidental): Académie des Sciences (Paris), Comptes Rendus, v. 181, p. 1108-1111.

Depéret, C., and Savorin, J., 1927, Le faune de reptiles et de poissons albiens de Timimoun (Sahara algérien): Société Géologique de France Bulletin, v. 27, p. 257-265. 
Gemmellaro, M., 1921, Rettili Maëstrichtiani d'Egitto: Giornale de Science naturale econ. Palermo, v. 32, p. 339-351.

Gonzalez, Louis, 1973, Geologic map and sections of the Jabal 'In quadrangle: Saudi Arabian Directorate General of Mineral Resources Geologic Map GM-2, 7 p.

Grasty, R., Miller, J.A., and Mohr, P.A., 1963, Preliminary results of $\mathrm{K}-\mathrm{Ar}$ age determinations, Trap Series basalts: Geophysical Observatory Addis Ababa Bulletin no. 6, (v. 3, no. 2), p. 97-101.

Grolier, Maurice J., and Overstreet, W.C., 1978, Geologic map of the Yemen Arab Republic: U.S. Geological Survey Miscellaneous Investigations Series, Map I-1143 B.

Hamilton, W.R., Whybrow, P.J., and McClure, H.A., 1978, Fauna of fossil mammals from the Miocene of Saudi Arabia: Nature, v. 274, no. 5668, p. 248-249.

Jones, P.W., and Rex, D.C., 1974, New dates from the Ethiopian plateau volcanics: Nature, v. 252, no. 5480, p. 218-219.

Karpoff, Roman, 1957, Sur l'existence de Maestrichtien au Nord de Djeddah (Arabie séoudite): Académie des Sciences (Paris), Comptes Rendus, v. 245, p. 1322-1324.

Lemoalle, J., and Dupont, B., 1973, Iron-bearing oolites and the present conditions of iron sedimentation in Lake Chad (Africa), p. 167-178, in Amstutz, G.C., and Bernard, A.J. (eds.), Ores in Sediments: New York, Springer-Verlag, 350 p.

Martin, Conrad, 1970, Preliminary investigation of cement materials in the Ta'if area, Saud Arabla: U,S, Geol. Survey open-file rept. (IR)SA-109, 18 p., 1 fig, , 1 table,

Meissner, C.R., Jr., and Ankary, Abdullah, 1972, Phosphorite deposits in the Sirhan-Turayf Basin, Kingdom of Saudi Arabia: Saudi Arabian Directorate General of Mineral Resources Report of Investigations 2, $27 \mathrm{p}$.

Mohr, P.A., 1975, Structural setting and evolution of Afar, p. 27-37, in Pilger, A. and Rösler, A., Afar depression of Ethiopia: Inter-Union Commission on Geodynamics, Scientific Report no. 14, v. 1, Stuttgart, E. Schweizerbartsche Verlagsbuchhandlung, $416 \mathrm{p}$.

Overstreet, W.C., Stoeser, D.B., Overstreet, E.F., and Goudarzi, G.H., 1977, Tertiary laterite of the As Sarat mountains, Asir Province, Kingdom of Saudi Arabia: Saudi Arabian Directorate General of Mineral Resources Bulletin 21, $30 \mathrm{p}$. 
Powers, R.W., Ramirez, L.F., Redmond, C.D., and Elberg, E.L., Jr., 1966, Geology of the Arabian Peninsula-sedimentary geology of Saudi Arabia: U.S. Geological Survey Professional paper $560 \mathrm{D}, 147 \mathrm{p}$.

Priem, M.F., 1897, Sur les poissons de l'Eocene du Mont Mokattam (Egypte): Société Géologique de France Bulletin, v. 25. p. $212-227$.

, 1914, Sur les vertébrés du Crétacé et de l'Eocène d'Egypte: Société Géologique de France Bulletin, v. 14, p. 366-382.

Romer, A.S., 1966, Vertebrate Paleontology: University of Chicago Press, $468 \mathrm{p}$.

Said, Rushdi, 1962, The Geology of Egypt: New York, Elsevier, $377 \mathrm{p}$.

Slaughter, B.H., and Thurmond, J.T., 1974, A lower Cenomanian (Cretaceous) Ichthyo-Fauna from the Bahariya Formation of Egypt: Geological Survey Egypt Annals 4, p. 25-40.

Stromer, Ernst, 1905, Die Fischreste des mittleren und oberen Eocäns von Ägypten: I. Die Selachier, Beitr. Pälaont. Geol. Osterr.-Ungarns, 18, p. 163-192.

Stromer, E., and Weiler, W., 1930, Ergebnisse der Forschungsreisen Prof. E. Stromers in den Wüsten Ägyptens. VI. Beschreibung von Wirbeltier-Resten aus dem nubischen Sandsteine oberägyptens und aus ägyptischen Phosphaten nebst Bemerkungen über die Geologies der Umgegend von Mahamid in oberägypten: Abhandlungen der Bayerischen Akademie der Wissenschaften Mathematisch-naturwissenschaftliche Abteilung, Neue Folge 7, p. 1-42.

Swinton, W.E., 1930, The fossil reptiles from Sokoto Province: Geological Survey Nigeria Bulletin, v. 13, p. 15-60.

Tabaste, Nicole, 1963, Etude des restes de poissons du Crétace Saharien: I.F.A.N., Dakar Mémoire Mélanges Ichthyologiques, v. 68 , p. $436-499$.

Tleel, J.W., 1973, Surface geology Damman Dome, Eastern Province, Saudi Arabia: American Association Petroleum Geologists, Bulletin, v. 57, no. 3, p. 558-576.

Tromp, S.W., 1950, The age and origin of the Red Sea graben: Geological Magazine, v. 87, p. 385-392.

White, E.I., 1934, Fossil fishes of Sokoto Province: Geological Survey Nigeria Bulletin, v. 14, p. 1-78.

Whiteman, A.J., 1971, The geology of the Sudan Republic: Oxford, Clarendon Press, 290 p. 